\title{
Age, Sex, and Reproductive Hormone Effects on Brain Serotonin-I A and Serotonin-2A Receptor Binding in a Healthy Population
}

\author{
Eydie L Moses-Kolko*,', Julie C Price ${ }^{2}$, Nilesh Shah ${ }^{3}$, Sarah Berga ${ }^{4}$, Susan M Sereika ${ }^{3,5}$, Patrick M Fisher ${ }^{6}$, \\ Rhaven Coleman ${ }^{3}$, Carl Becker ${ }^{2}$, N Scott Mason ${ }^{2}$, Tammy Loucks $^{4}$ and Carolyn C Meltzer ${ }^{7}$ \\ 'Department of Psychiatry, Western Psychiatric Institute and Clinic, University of Pittsburgh Medical Center, Pittsburgh, PA, USA; ${ }^{2}$ Department of \\ Radiology, University of Pittsburgh Medical Center, Pittsburgh, PA, USA; ${ }^{3}$ Department of Biostatistics and Graduate School of Public Health, \\ University of Pittsburgh and University of Pittsburgh Medical Center, Pittsburgh, PA, USA; ${ }^{4}$ Departments of Gynecology and Obstetrics and \\ Psychiatry, Emory University School of Medicine, Atlanta, GA, USA; ${ }^{5}$ Department of Health and Community Systems, School of Nursing, \\ Pittsburgh, PA, USA; ${ }^{6}$ Center for Neuroscience and Center for the Neural Basis of Cognition, University of Pittsburgh, Pittsburgh, PA, USA; \\ ${ }^{7}$ Department of Radiology and Imaging Sciences, Emory University School of Medicine, Atlanta, GA, USA
}

\begin{abstract}
There is a need for rigorous positron emission tomography (PET) and endocrine methods to address inconsistencies in the literature regarding age, sex, and reproductive hormone effects on central serotonin $(5 \mathrm{HT})$ IA and $2 \mathrm{~A}$ receptor binding potential (BP). Healthy subjects $(n=71)$, aged $20-80$ years, underwent $5 \mathrm{HTIA}$ and $2 \mathrm{~A}$ receptor imaging using consecutive 90-min PET acquisitions with $\left[{ }^{1} \mathrm{C}\right]$ WAY 100635 and $\left[{ }^{18} \mathrm{~F}\right]$ altanserin. Logan graphical analysis was used to derive BP using atrophy-corrected distribution volume $\left(V_{T}\right)$ in prefrontal, mesiotemporal, occipital cortices, and raphe nucleus (5HTIA only). We used multivariate linear regression modeling to examine BP relationships with age, age ${ }^{2}$, sex, and hormone concentrations, with post hoc regional significance set at $p<0.008$. There were small postsynaptic 5HTIA receptor BP increases with age and estradiol concentration in women $(p=0.004-0.005)$ and a tendency for small $5 \mathrm{HT}$ IA receptor BP declines with age and free androgen index in men $(p=0.05-0.06)$. Raphe 5HTIA receptor BP decreased $4.5 \%$ per decade of age $(p=0.05)$, primarily in men. There was a trend for $15 \%$ receptor reductions in prefrontal cortical regions in women relative to men (post hoc $p=0.03-0.10$ ). The significant decline in $5 \mathrm{HT} 2 \mathrm{~A}$ receptor BP relative to age (8\% per decade; $p<0.00$ I) was not related to sex or hormone concentrations. In conclusion, endocrine standardization minimized confounding introduced by endogenous hormonal fluctuations and reproductive stage and permitted us to detect small effects of sex, age, and endogenous sex steroid exposures upon 5HTIA binding. Reduced prefrontal cortical 5HTIA receptor BP in women vs men, but increased $5 \mathrm{HTI}$ A receptor BP with aging in women, may partially explain the increased susceptibility to affective disorders in women during their reproductive years that is mitigated in later life. $5 \mathrm{HTI}$ A receptor decreases with age in men might contribute to the known increased risk for suicide in men over age 75 years. Low hormone concentrations in adults $<50$ years of age may be associated with more extreme $5 \mathrm{HT}$ IA receptor $\mathrm{BP}$ values, but remains to be studied further. The $5 \mathrm{HT} 2 \mathrm{~A}$ receptor declines with age were not related to sex or hormone concentrations in this sample. Additional study in clinical populations is needed to further examine the affective role of sex-hormone-serotonin receptor relationships.

Neuropsychopharmacology (20 II) 36, 2729-2740; doi: I0.1038/npp.20II.I63; published online 17 August 20I I
\end{abstract}

Keywords: serotonin receptors; age; sex; ${ }^{[1 / C]}$ WAY I00635; $\left[{ }^{18} \mathrm{~F}\right]$ altanserin; PET imaging

\section{INTRODUCTION}

Epidemiological studies highlight differential sex and sexby-age interactional patterns in the incidence of depression and suicide. The life onset risk for major depression is

*Correspondence: EL Moses-Kolko, Western Psychiatric Institute and Clinic, University of Pittsburgh Medical Center, 3811 O'Hara Street, Pittsburgh, PA 15213, USA, Tel: + 412624 9152, Fax: + | 412383 8336, E-mail: MosesEL@upmc.edu

Received 9 March 20I I; revised 24 June 201 I; accepted I4 July 201 I 1.6-fold increased in women relative to men aged 10-50 years (Kessler et al, 1993), but equalizes between women and men after age 55 years (Bebbington et al, 1998). Suicide attempts are fourfold more lethal in men than women, with the highest suicide rate occurring in men over age 75 years (Szanto et al, 2002). To what extent these patterns relate to brain effects of age-related decline in sex hormones (Feldman et al, 2002; Soules et al, 2001) or sex differences remain unknown.

The serotonin (5HT) $1 \mathrm{~A}$ and $2 \mathrm{~A}$ receptors systems in prefrontal, mesiotemporal, and occipital cortices and raphe 
nucleus (5HT1A only) have been explored as potential mediators of sex, age, and hormone effects on mood, given abnormalities noted in affective disorders (Drevets et al, 2007; Meyer, 2008) and modulation by sex hormones. 5HT acting at 5HT1A somatodendritic autoreceptors on raphe nucleus serotonin neurons negatively regulates downstream $5 \mathrm{HT}$ release and $5 \mathrm{HT}$ activity at postsynaptic $5 \mathrm{HT} 1 \mathrm{~A}$, and 5HT2A receptors have inhibitory and excitatory actions on cortical targets, respectively (Barnes and Sharp, 1999; Sharp et al, 2007), making these receptors critical modulators of global 5HT tone.

Age and sex relationships to 5HT1A receptor binding in healthy adults have been inconsistent, potentially because of limitations in postmortem and positron emission tomography (PET) methods (Arango et al, 1995; Cheetham et al, 1990; Matsubara et al, 1991; Palego et al, 1997; Costes et al, 2005; Jovanovic et al, 2008; Meltzer et al, 2001; Parsey et al, 2002; Rabiner et al, 2002; Stein et al, 2008; Tauscher et al, 2001). Potential sex differences in nonspecific binding (Parsey et al, 2002) and menstrual cycle-related receptor fluctuations (Jovanovic et al, 2006) in $\left[{ }^{11} \mathrm{C}\right] \mathrm{WAY} 100635$ PET studies might have presented confounds. Furthermore, potential inverse relationships between hormones (estradiol; androgens, as mediated by aromatization of testosterone to estradiol) and 5HT1A receptor expression (Osterlund et al, 2000; Osterlund and Hurd, 1998; Pecins-Thompson and Bethea, 1999; Ricci et al, 2006; Simon et al, 1998; Zhang et al, 1999) deserve study in humans to explicate age-sex5 HT relationships.

Although the weight of evidence reveals an absence of sex differences in 5HT2A BP ${ }_{\mathrm{P}}$ (Adams et al, 2004; Biver et al, 1996; Frokjaer et al, 2009; Meyer et al, 1999; Rosier et al, 1996), 5HT2A receptor binding was positively associated with increases in estradiol in men and women (Frokjaer et al, 2010; Kugaya et al, 2003; Moses et al, 2000), similar to experimental animals (Cyr et al, 1998; Sumner and Fink, 1995, 1998). Whether the well-described inverse association between age and 5HT2A receptor binding (Meltzer et al, 1998) differs by sex, as suggested by nonlinear 5HT2A receptor decreases that were greater in midlife (ages 20-45 years) relative to older subjects (ages $46-70$ years) in a predominantly female sample (Sheline et al, 2002), remains to be studied.

In the current study, we addressed prior limitations and unanswered questions through scanning of a large cohort $(n=71)$ of healthy subjects aged $20-80$ years with arterialbased quantification of PET data with assessment of sex, age, and hormone effects on nonspecific tracer factors. We 'standardized' women endocrinologically by scanning ovulatory, premenopausal women in their follicular menstrual cycle phase and by confirming hypogondal status in postmenopausal women. Regions of interest included prefrontal, mesiotemporal, and occipital cortices as well as raphe nucleus (5HT1A only). We hypothesized that the abrupt menopausal decline in estradiol would be associated with increases of 5HT1A receptor binding potential (BP) with aging that would be less pronounced in men, given more gradual androgen decreases with aging. We also tested the hypothesis that the age-related decline in 5HT2A was associated with decreased gonadal steroids in late life (Moses et al, 2000), and sought to replicate the curvilinear inverse relationship between age and 5HT2A receptor binding in women (Sheline et al, 2002) and the linear inverse relationship between age and 5HT2A receptor binding in men (Meltzer et al, 1998). We hypothesized that $5 \mathrm{HT}$ receptor binding in all brain regions examined would have consistent relationships with age, sex, and steroids as suggested by consistent $5 \mathrm{HT}$ receptor genomic expression across brain regions (David et al, 2005).

\section{SUBJECTS AND METHODS}

\section{Subjects}

5HT receptor data in relation to amygdala activity to negative emotional faces within a subset of this cohort have been previously published (Fisher et al, 2006, 2009). Subjects provided written informed consent as approved by the University of Pittsburgh Biomedical Institutional Review Board. Healthy subjects screened by the Structured Clinical Interview for DSM-IV (First et al, 1998) and the Hamilton Scale for Depression (Hamilton, 1960) were recruited in a sex-balanced fashion from age 18 through 80 years. To optimize scan acquisition in women during times of low circulating steroids, we excluded perimenopausal women, whose hormone concentrations are less predictable. Premenopausal women were younger than age 50 years and were scanned after confirmation of an ovulatory cycle (21-day progesterone $\geqslant 25 \mathrm{nmol} / \mathrm{l})$ and between days $2-9$ of a subsequent menstrual cycle. Postmenopausal women were $\geqslant 50$ years of age with estradiol concentrations $<40 \mathrm{pg} / \mathrm{ml}$, FSH $>30 \mathrm{IU} / \mathrm{l}$, and $>1$ year of amenorrhea. Premenopausal women were free from oral contraceptives for 3 months or depo-medroxyprogesterone acetate for 1 year, were more than 6 months post-breastfeeding, and more than 2 years postpartum. Postmenopausal women were free from hormone treatment in the preceding 2 years and had $<5$ years of lifetime hormone therapy. Although prior hysterectomy or oopherectomy were excluded initially, we ultimately included 3 women with remote hysterectomy/oopherectomy because it was so common in women over 60 years.

Subjects had no personal history of a major Axis I disorder and no family history of a mood or psychotic disorder. Subjects were excluded if they had medical or neurological illnesses likely to affect cerebral physiology or anatomy, gross abnormalities of brain structure evident by magnetic resonance images (MRI), suicidal intent, substance abuse within 1 year, lifetime history of substance dependence (other than nicotine), eating disorders, or exposure to medications likely to alter cerebral physiology. After consent and screening of 176 subjects, 115 were eligible, of whom 79 were scanned and 70 and 62 produced usable WAY100635 and altanserin data, respectively (Supplementary Figure A).

Endogenous hormones were characterized through menstrual cycle charting and scan day measurement (09451215 hours) of thyroid-stimulating hormone (TSH), free thyroxine (fT4), dehydroepiandrosterone sulfate (DHEAS), and sex hormone-binding globulin (SHBG) in all subjects and estradiol and progesterone in women and total testosterone (TT) in men. Free androgen index (FAI) was calculated as (total testosterone $(\mathrm{nmol} / \mathrm{l}) \div$ sex hormonebinding globulin $(\mathrm{nmol} / \mathrm{l})) \times 100$. Estradiol, progesterone, 
TT, fT4 (Coat-A-Count, Siemens, Los Angeles, CA), and DHEAS (Diagnostic Systems Laboratories, Webster, TX) were measured by radioimmunoassay. TSH and SHBG were measured by time-resolved fluroimmunometric assay (DELFIA, Perkin Elmer, Boston, MA). Intra- and interassay coefficients of variation (CVs) for each assay were $<10 \%$. All specimens were analyzed in duplicate and in the same assay run to reduce variability. Log-base 10 transformation was used to induce a normal distribution for use in models of receptor binding.

\section{Image Acquisition}

To provide an anatomical framework for PET data analysis, MRIs were obtained using a $1.5 \mathrm{~T}$ Signa Scanner (GE Healthcare, Milwaukee, WI) and a three-dimensional (3D) spoiled gradient recalled sequence. PET scans were acquired on an ECAT HR + PET scanner (Siemens, Erlangen, Germany) in 3D mode (Meltzer et al, 2004). A 10-min transmission scan was obtained for attenuation correction using rotating $68 \mathrm{Ge} / 68 \mathrm{Ga}$ rods. Subjects underwent consecutive 90-min PET acquisitions of both $\left[{ }^{11} \mathrm{C}\right]$ WAY100635 and $\left[{ }^{18} \mathrm{~F}\right]$ altanserin, separated by $10 \mathrm{~min}$, which allowed for $100 \mathrm{~min}$ (five half-lives) between radioligand injections. Radiosyntheses of [carbonyl- $\left.{ }^{11} \mathrm{C}\right]$ WAY100635 (McCarron et al, 1996) and $\left[{ }^{18} \mathrm{~F}\right]$ altanserin (Lemaire et al, 1991; Soloff et al, 2010) were performed as previously described. The $\left[{ }^{11} \mathrm{C}\right]$ WAY100635 dynamic emission scan (34 frames of increasing length over $90 \mathrm{~min}$ ) occurred after IV bolus administration of 8.0 to $16.6 \mathrm{mCi}($ mean $\pm \mathrm{SD}=13.9 \pm 2.0$ ) of high specific activity $\left[{ }^{11} \mathrm{C}\right]$ WAY100635 $(2.1 \pm 1.1 \mathrm{mCi} /$ $\mathrm{nmol}$ at the time of injection). The $\left[{ }^{18} \mathrm{~F}\right]$ altanserin dynamic emission scan (22 frames of increasing length over $90 \mathrm{~min}$ ) occurred after IV bolus administration of 6.3 to $7.8 \mathrm{mCi}$ (mean $\pm \mathrm{SD}=7.2 \pm 0.3$ ) of high specific activity $\left[{ }^{18} \mathrm{~F}\right]$ altanserin $(11.3 \pm 17.2 \mathrm{mCi} / \mathrm{nmol}$ at time of injection). Arterial blood sampled during scanning was corrected for radiolabeled metabolites to compute the plasma input function for $\left[{ }^{11} \mathrm{C}\right]$ WAY100635 (Bailer et al, 2005) and $\left[{ }^{18} \mathrm{~F}\right]$ altanserin (Henry et al, 2004) scans. Plasma samples of $\left[{ }^{11} \mathrm{C}\right]$ WAY100635 and $\left[{ }^{18} \mathrm{~F}\right]$ altanserin were obtained at 2 , $10,30,60$, and $90 \mathrm{~min}$ after injection to correct the input function for radiolabeled metabolites. Plasma protein binding of $\left[{ }^{11} \mathrm{C}\right]$ WAY 100635 and $\left[{ }^{18} \mathrm{~F}\right]$ altanserin was measured by ultracentrifugation using the Centrifree membranes to determine the free tracer fraction $\left(f_{\mathrm{p}}\right)$.

\section{Image Analysis}

Brain regions of interest (ROIs) (average of right and left hemispheres) selected $a$ priori based upon regional 5HT1A and 5HT2A receptor abnormalities in depression and suicide and associations with sex, age, and hormones were: amygdala, hippocampus, lateral orbitofrontal cortex, pregenual cortex, subgenual cortex, anterior cingulate gyrus, occipital cortex, and raphe nucleus (encompassing median and dorsal raphe-5HT1A receptor studies only). Because the raphe nuclei cannot be resolved on MR, ROI placement was guided along the $z$ axis by PET scan and was drawn on seven MR planes superior to the interpeduncular cistern (Meltzer et al, 2001). A reference region for assessing nonspecifically bound and free radioligand, $\left[{ }^{11} \mathrm{C}\right]$ WAY100635 $V_{\mathrm{ND}}$, was defined in cerebellar gray matter using guidelines that excluded the vermis (Parsey et al, 2005) and minimized the spill-in effects from neighboring cortex (Bailer et al, 2005; Drevets et al, 1999; Meltzer et al, 2001, 2004; Price et al, 2002b). The cerebellar white matter was not used because it did not exhibit in vivo kinetics consistent with nondisplaceable uptake in 5HT1A receptorrich areas. The cerebellum was assumed to have minimal levels of specific $\left[{ }^{18} \mathrm{~F}\right]$ altanserin binding and to provide a reasonable estimate of $\left[{ }^{18} \mathrm{~F}\right]$ altanserin $V_{\mathrm{ND}}$, despite overestimation of the nonspecific component as a result of the blood- brain barrier-permeable radiometabolites (Lammertsma and Hume, 1996).

PET images were aligned with MR images using automated image registration (Woods et al, 1993). ROIs were manually traced on the MR image using a modified version of the IDL-based (Interactive Data Language, Boulder, CO) computer program, ROITOOL, of CTI PET Systems (Knoxville, TN) according to published guidelines (Drevets et al, 1999; Meltzer et al, 2001). Regional tissue time-activity concentrations were obtained from the dynamic PET image for each ROI. Logan graphical analysis with generalized linear least squares smoothing (Bailer et al, 2005; Logan et al, 2001; Price et al, 2002a) was applied to the arterial input function and regional tissue time-activity concentrations to derive $\left[{ }^{11} \mathrm{C}\right] \mathrm{WAY} 100635$ and $\left[{ }^{18} \mathrm{~F}\right]$ altanserin distribution volume $\left(V_{\mathrm{T}}\right)$. To control for the dilutional effect of expanded CSF spaces on brain radioactivity concentrations, we corrected $V_{\mathrm{T}}$ for atrophy in all subjects using MR-based correction factors that varied from 0 to 1 (no dilution) (Meltzer et al, 1990, 1999). The $\left[{ }^{11} \mathrm{C}\right]$ WAY100635 and $\left[{ }^{18} \mathrm{~F}\right]$ altanserin binding potential measures $\left(\mathrm{BP}_{\mathrm{P}}\right.$ and $\left.\mathrm{BP}_{\mathrm{ND}}\right)$ were derived according to traditional relationships: $\mathrm{BP}_{\mathrm{P}}=V_{\mathrm{T}}-V_{\mathrm{ND}}$ and $\mathrm{BP}_{\mathrm{ND}}=V_{\mathrm{T}} /$ $V_{\mathrm{ND}^{-1}}$ (Innis et al, 2007), where $V_{\mathrm{T}}$ is regional distribution volume of tracer and $V_{\mathrm{ND}}$ is cerebellar reference tissue volume of distribution. We derived both $\mathrm{BP}_{\mathrm{P}}$ and $\mathrm{BP}_{\mathrm{ND}}$ as both measures have been used in prior 5HT1A and 5HT2A receptor studies. $\mathrm{BP}_{\mathrm{P}}$ relies upon $f_{\mathrm{p}}$ in plasma whereas $\mathrm{BP}$ relies upon free and nonspecific binding in the cerebellar reference tissue $\left(V_{\mathrm{ND}}\right)$. Because our study results are largely consistent for the two BP outcome measures, tabulated and graphical data are presented herein for $\mathrm{BP}_{\mathrm{P}}$ and in Supplementary Tables for $\mathrm{BP}_{\mathrm{ND}}$.

\section{Statistical Analysis}

We used multivariate general linear regression modeling in which we tested the main effects of age, age ${ }^{2}$, sex, and an age-by-sex interaction on atrophy correction factors, $f_{\mathrm{p}}$, $V_{\mathrm{ND}}, \mathrm{BP}_{\mathrm{ND}}$, and $\mathrm{BP}_{\mathrm{P}}$, for all regions of interest, separately for $5 \mathrm{HT} 1 \mathrm{~A}$ and $2 \mathrm{~A}$ receptor binding. $5 \mathrm{HT} 1 \mathrm{~A}$ receptor $\mathrm{BP}$ was evaluated in two separate regression models given different physiology of postsynaptic from presynaptic (raphe) regions, whereas 5HT2A receptor BP was evaluated in a single regression model. In all models, age was centered to limit nonessential multicollinearity that is induced with creation of the interaction term and higher-order effects that are a function of age. We present tabulated regression coefficients $(\beta)$ (Tables 2 and 3 ) as centered age 'per decade' ( $\beta$ divided by 10 ) to aid interpretation because regression coefficient values were small. We followed the 
same procedure in sex-stratified groups, in which $\log _{10}$ (estradiol) and $\log _{10}$ (free androgen index) were added as covariates to the models. Our threshold for significance was $p<0.05$ for each multivariate six-region regression as well as regressions for cerebellar $V_{\mathrm{T}}$ and raphe $\mathrm{BP}$, which were control and secondary ROIs, respectively. We set $\alpha=0.008$ $(0.05 / 6)$ to adjust for multiple post hoc exploratory univariate tests by region. Linear mixed modeling was used in the analysis of age and sex effects on the metabolism of parent radioligand over the course of scanning with denominator degrees of freedom approximated based on the Satterthwaite method.

We evaluated the effects of potential confounding variables by examining the relationship of sex, age, and BP with subject characteristics (Table 1) using linear regression and contingency table analysis with $\chi^{2}$ tests of independence. Variables that were at least marginally associated with the dependent measure $(p<0.10$; body mass index (BMI), hormone concentrations (TSH, free T4, and DHEAS), and injected radioligand mass) were then added together to the regression models. All of these covariates were ultimately dropped from the final model because of absence of significant association with receptor $\mathrm{BP}$.

\section{RESULTS}

\section{Demographics}

Of the 71 subjects with usable $\left[{ }^{11} \mathrm{C}\right]$ WAY 100635 or $\left[{ }^{18} \mathrm{~F}\right]$ altanserin scan data, there were 37 men and 34 women participants with age that ranged from 20.1 to 80.6 years (Table 1$)$. The sample was largely Caucasian $(83 \%)$ and well educated with $62 \%$ having received a college or postgraduate degree. Depressive and anxiety scale scores were not different on the basis of sex or age.

\section{Reproductive Hormone Data}

Three postmenopausal women (ages 67-80 years) had past hysterectomy and/or oopherectomy between ages 40-42 years. Estradiol concentration was higher in the

Table I Sample Characteristics (Mean \pm SD)

\begin{tabular}{|c|c|c|c|c|}
\hline \multirow{3}{*}{$n$} & \multicolumn{2}{|l|}{ Men } & \multicolumn{2}{|l|}{ Women } \\
\hline & 37 & & 34 & \\
\hline & Mean \pm SD or proportion & $\%$ & Mean \pm SD or proportion & $\%$ \\
\hline Age & $47.88 \pm 18.00$ & & $48.57 \pm 16.98$ & \\
\hline Education $\geqslant$ college degree & $22 / 37$ & $59.46 \%$ & $22 / 34$ & $64.71 \%$ \\
\hline Caucasian & $32 / 37$ & $86.49 \%$ & $27 / 34$ & $79.41 \%$ \\
\hline STAI raw score trait anxiety & $27.35 \pm 5.41$ & & $29.03 \pm 6.60$ & \\
\hline Body mass index & $25.63 \pm 3.65$ & & $25.59 \pm 4.76$ & \\
\hline $\mathrm{TSH}(\mu \mathrm{lU} / \mathrm{ml})$ & $1.53 \pm 1.14$ & & $1.88 \pm 2.05$ & \\
\hline Free thyroxine $(\mathrm{ng} / \mathrm{dl})$ & $1.02 \pm 0.27$ & & $1.37 \pm 1.57$ & \\
\hline Estradiol $^{a}(\mathrm{pg} / \mathrm{ml})$ & \pm & & $20.97 \pm 29.67$ & \\
\hline \multicolumn{5}{|l|}{ Radioligand characteristics } \\
\hline WAYI00635 cerebellar $V_{T}\left(\mathrm{ml} / \mathrm{cm}^{3}\right)$ & $0.99 \pm 0.24$ & & $0.98 \pm 0.29$ & \\
\hline WAYI00635 injected dose (mCi) & $14.83 \pm 1.90$ & & $|3.68 \pm 2.0|$ & \\
\hline WAYI00635 specific activity (mCi/nmol) & $2.14 \pm 1.05$ & & $1.95 \pm 1.02$ & \\
\hline WAYI00635 injected mass $(\mu \mathrm{g})$ & $3.62 \pm 2.17$ & & $3.69 \pm 1.79$ & \\
\hline WAYI00635 $f_{\mathrm{p}}$ & $0.11 \pm 0.04$ & & $0.11 \pm 0.07$ & \\
\hline Altanserin cerebellar V粒* $\left(\mathrm{ml} / \mathrm{cm}^{3}\right)$ & $1.36 \pm 0.39$ & & $1.53 \pm 0.35$ & \\
\hline Altanserin injected dose (mCi) & $7.12 \pm 0.37$ & & $7.19 \pm 0.29$ & \\
\hline Altanserin specific activity $(\mathrm{mCi} / \mathrm{nmol})$ & $11.06 \pm 11.73$ & & $12.23 \pm 22.43$ & \\
\hline Altanserin injected mass***** $(\mu \mathrm{g})$ & $0.70 \pm 0.70$ & & $0.93 \pm 0.92$ & \\
\hline
\end{tabular}

a Pearson's correlations relative to age: Estradiol $-0.50, p<0.0$ I. Free androgen index $-0.69, p<0.00$ I. DHEAS (male) $-0.30,0.5<p<0.10$. DHEAS (female) -0.44 , $p<0.05$.

For age and sex effect, $*$ $p<0.05$.

For age $\times$ sex interaction, age, and sex effect, ${ }^{*} * p<0.05$.

For age $\times$ sex interaction and age effect, $* * * 0.5<p<0.10$. 
postmenopausal intact women (7.40 vs $4.00 \mathrm{ng} / \mathrm{ml})$. Mean scan day estradiol concentration among all women participants was low $(20.4 \pm 29.5 \mathrm{pg} / \mathrm{ml})$, as was progesterone in premenopausal women $(0.5 \pm 0.2 \mathrm{ng} / \mathrm{ml})$, indications of accurate scan timing during the early follicular phase or menopause (Table 1 ). FAI in men was $4.7 \pm 2.1$. As expected, estradiol and FAI concentrations were inversely correlated with age, but were not thought to cause multicollinearity in our regressions because correlations were $<0.8$. Pearson bivariate correlations and traditional multicollinearity statistics were examined in univariate models without observed multicollinearity.

\section{Potentially Confounding PET Variables: Atrophy Correction, Radioligand CER $V_{\mathrm{T}}$, Free Fraction, and Metabolism}

Atrophy-correction factors across all ROIs decreased with aging as expected (increasing atrophy) (mean $\beta<-0.05$ per decade, $p<0.001)$. Atrophy-correction factors were increased in women relative to men (mean $\beta=0.014$ per decade, $p=0.004)$. There were no significant associations for age or sex, or age-by-sex interactions on $\left[{ }^{11} \mathrm{C}\right]$ WAY100635 and $\left[{ }^{18} \mathrm{~F}\right]$ Altanserin injected mass or on Altanserin metabolism over the scan duration. There was a significant sex-by-age interaction $(p=0.013)$ on the free fraction $\left(f_{\mathrm{p}}\right)$ of $\left[{ }^{11} \mathrm{C}\right]$ WAY100635 in plasma, with an ageassociated increase in men and analogous decrease in women, that did not impact relationships of age, sex, and hormone concentration with WAY100635 $\mathrm{BP}_{\mathrm{P}}$ (Supplementary Table B). Altanserin $f_{\mathrm{p}}$, low as described previously (Haugbol et al, 2007), was not related to age or sex variables.
In the full sample of men and women, 5HT1A cerebellar $V_{\mathrm{T}}$ trended toward a decline with age $(\beta=-0.03$ per decade of life, $p=0.07$ ), that plateaued at later ages, as described by a significant age ${ }^{2}$ association with $V_{\mathrm{T}}(\beta<0.01$ per decade, $p=0.01)$. This later-age plateauing was also noted for women ( $\beta=0.01$ per decade, $p=0.002$; Table 2 ).

$5 \mathrm{HT} 2 \mathrm{~A}$ receptor cerebellar $V_{\mathrm{T}}$ increased with age in the full sample $(\beta=0.08$ per decade, $p=0.002)$, as driven by this relationship in women $(\beta=0.16$ per decade, $p=0.001)$. In women, estradiol concentration was also associated with increased cerebellar $V_{\mathrm{T}}(\beta=0.30 ; p=0.03$; Table 3$)$.

\section{HT1A Receptor PET Data}

There was no significant age-by-sex interaction for 5HT1A receptor $\mathrm{BP}$ (see Table 2). 5HT1A receptor $\mathrm{BP}$ was reduced in women relative to men in postsynaptic prefrontal (LOF, SGC, PRE) and occipital (OCC) regions in the range of 16$19 \%\left(\mathrm{BP}_{\mathrm{ND}}\right)$ and $9-18 \%\left(\mathrm{BP}_{\mathrm{P}}\right)$ (post hoc $p=0.03-0.10$; Figure 1), but did not survive the post hoc regional correction for multiple testing $(p<0.008)$. 5HT1A receptor $\mathrm{BP}$ was nonsignificantly lower in women relative to men in amygdala and raphe regions as well. Raphe $5 \mathrm{HT} 1 \mathrm{~A}$ receptor BP was inversely related to age or age ${ }^{2}(4.5 \%$ decrease per decade; $p=0.05$ ).

In the sex-stratified model for postsynaptic 5HT1A receptor BP in men, there was a small inverse relationship between BP and age $(p=0.05)$ and FAI $(p=0.06)$, accounting for only $1-9 \%$ of the variance in BP. These results remained at the borderline of significance in a sensitivity analysis that excluded an older male outlier with low BP values. Large magnitude inverse relationships between hippocampal BP and age $(\beta=-0.74 ; p=0.09)$ and $\log _{10}$

Table 2 Model Results for Age, Sex, and Steroid Hormone Effects on 5HTIA Receptor BP

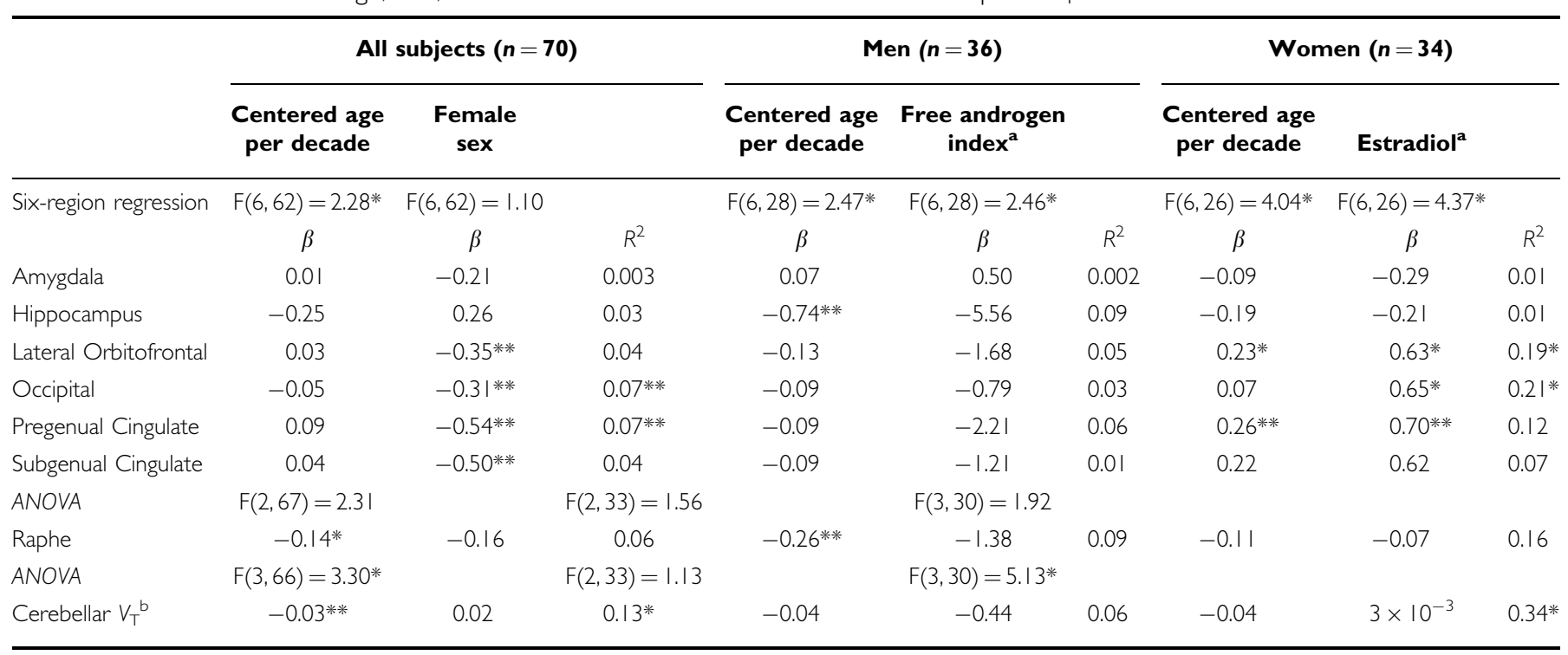

aLog-base 10 transformed.

${ }^{b}$ Not reported in table is the significant, small relationship between age ${ }^{2}$ and Cerebellar $V_{T}$ in the full sample and women subsample.

* $p<0.05$.

$* * 0.05<p<0.10$.

Here, $\beta$ is the unstandardized regression coefficient. 
Table 3 Model Results for Age, Sex, and Steroid Hormone Effects on 5HT2A Receptor BP

\begin{tabular}{|c|c|c|c|c|c|c|c|c|c|c|c|}
\hline & \multicolumn{4}{|c|}{ All subjects $(n=62)$} & \multicolumn{3}{|c|}{ Men $(n=33)$} & \multicolumn{4}{|c|}{ Women $(n=29)$} \\
\hline & $\begin{array}{l}\text { Centered } \\
\text { age per } \\
\text { decade }\end{array}$ & $\begin{array}{l}\text { Centered } \\
\text { age }^{2} \text { per } \\
\text { decade }\end{array}$ & $\begin{array}{c}\text { Female } \\
\text { Sex }\end{array}$ & & $\begin{array}{l}\text { Centered } \\
\text { age per } \\
\text { decade }\end{array}$ & $\begin{array}{c}\begin{array}{c}\text { Free } \\
\text { androgen } \\
\text { index }\end{array} \\
\text { a }\end{array}$ & & $\begin{array}{l}\text { Centered } \\
\text { age per } \\
\text { decade }\end{array}$ & $\begin{array}{l}\text { Centered } \\
\text { age }^{2} \text { per } \\
\text { decade }\end{array}$ & Estradiol $^{\mathbf{a}}$ & \\
\hline \multirow{2}{*}{$\begin{array}{l}\text { Six-region } \\
\text { regression }\end{array}$} & $F(6,53)=7.99 *$ & $F(6,53)=2.91 * *$ & $F(6,53)=1.06$ & & $F(6,25)=3.11 * * *$ & $F(6,25)=1.22$ & & $F(6,20)=4.46^{* *}$ & $F(6,20)=2.79 * *$ & $F(6,20)=2.20 * * *$ & \\
\hline & $\beta$ & $\beta$ & $\beta$ & $R^{2}$ & $\beta$ & $\beta$ & $R^{2}$ & $\beta$ & $\beta$ & $\beta$ & $R^{2}$ \\
\hline Amygdala & $-0.06 *$ & $<0.001$ & $0.11 * *$ & $0.29 *$ & $-0.08 * *$ & -0.41 & $0.22 * *$ & $-0.09 * *$ & $<0.001$ & -0.07 & $0.46 * *$ \\
\hline Hippocampus & $-0.07 *$ & $<0.001$ & 0.03 & $0.24 * *$ & -0.05 & 0.14 & 0.12 & $-0.13 *$ & $<0.001$ & $-0.15 * *$ & $0.60 *$ \\
\hline $\begin{array}{l}\text { Lateral } \\
\text { Orbitofrontal }\end{array}$ & $-0.16 *$ & $<0.00 \mathrm{I}^{\mathrm{a}}$ & 0.13 & $0.41 *$ & $-0.19 *$ & -0.49 & $0.35 * *$ & $-0.12 * *$ & $<\left.0.00\right|^{* * *}$ & 0.15 & $0.53^{*}$ \\
\hline Occipital & $-0.15^{*}$ & $<-0.001$ & 0.15 & $0.40 *$ & $-0.21 *$ & -0.85 & 0.40 *** & $-0.13 * *$ & $<0.001$ & 0.06 & $0.47 * *$ \\
\hline Pregenual Cingulate & $-0.15^{*}$ & $<0.001$ & 0.20 ****** & $0.34 *$ & $-0.20 * *$ & -0.93 & $0.26 * *$ & $-0.15 * *$ & $<0.001$ & 0.07 & $0.47^{* * * *}$ \\
\hline Subgenual Cingulate & $-0.17^{*}$ & $<0.001$ & 0.17 & $0.30 *$ & $-0.15^{* * * * *}$ & -0.02 & $0.18 * *$ & $-0.14 * *$ & $<\left.0.00\right|^{* * * *}$ & 0.17 & $0.50 *$ \\
\hline \multirow[t]{2}{*}{ ANOVA } & $F(2,59)=6.97^{* * *}$ & & & $F(2,30)=1.71$ & & $F(2,26)=7.3 * *$ & & & & & \\
\hline & $\beta$ & - & $\beta$ & $R^{2}$ & $\beta$ & $\beta$ & - & $\beta$ & $\beta$ & $\beta$ & $R^{2}$ \\
\hline Cerebellar $V_{T}$ & $0.08 * *$ & - & $0.15^{* * * * *}$ & $0.19 * *$ & 0.07 & -0.02 & 0.10 & $0.16 * *$ & - & 0.30 *** & $0.36^{\text {***** }}$ \\
\hline
\end{tabular}

aLog-base 10 transformed.

* $p<0.001$.

$* * 0<0.05$. **** $0.05<p<0.10$.

Here, $\beta$ is the unstandardized regression coefficient.

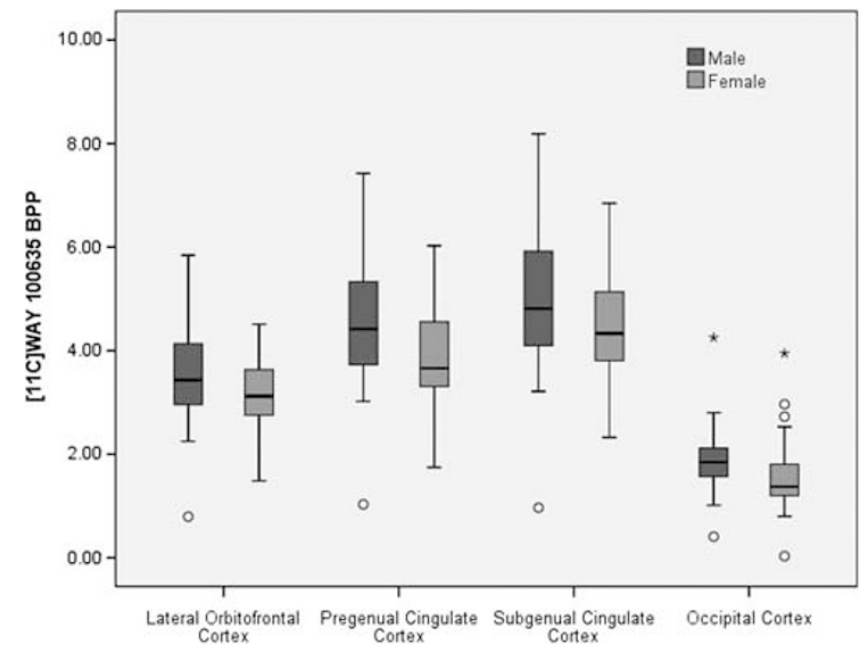

Figure I Reduced cortical 5HTIA receptor binding in women relative to men. Postsynaptic $5 \mathrm{HTI}$ A receptor $\mathrm{BP}_{\mathrm{p}}$ was reduced in women relative to men in lateral orbitofrontal $(9.3 \% ; p=0.06)$, subgenual $(10.5 \%$, $p=0.06)$, pregenual $(12.4 \%, p=0.03)$, and occipital cortex $(18.0 \%$; $p=0.03$ ). The $\mathrm{BP}_{\mathrm{ND}}$ and $\mathrm{BP}$ r results were entirely consistent (Supplementary Table A). Of note is one consistently extreme value in the male sample. Sensitivity analysis excluding this subject did not impact these results. This pattern of reduced $5 \mathrm{HTI}$ A receptor $\mathrm{BP}_{\mathrm{P}}$ in women could contribute to the greater risk for affective disorders in women relative to men!. * Extreme outliers, ${ }^{\circ}$ outlier.

(FAI; $\beta=-5.56 ; p=0.19$ ) were not significant. The inverse relationship between 5 HT1A receptor BP and FAI appeared to be driven by high receptor $\mathrm{BP}$ in several men $<50$ years old with low FAI values (Supplementary Figure B1). Presynaptic raphe 5HT1A receptor $\mathrm{BP}$ tended to be inversely related to age in men $(\beta=-0.26 ; p=0.096)$, but did not survive the sensitivity analysis.

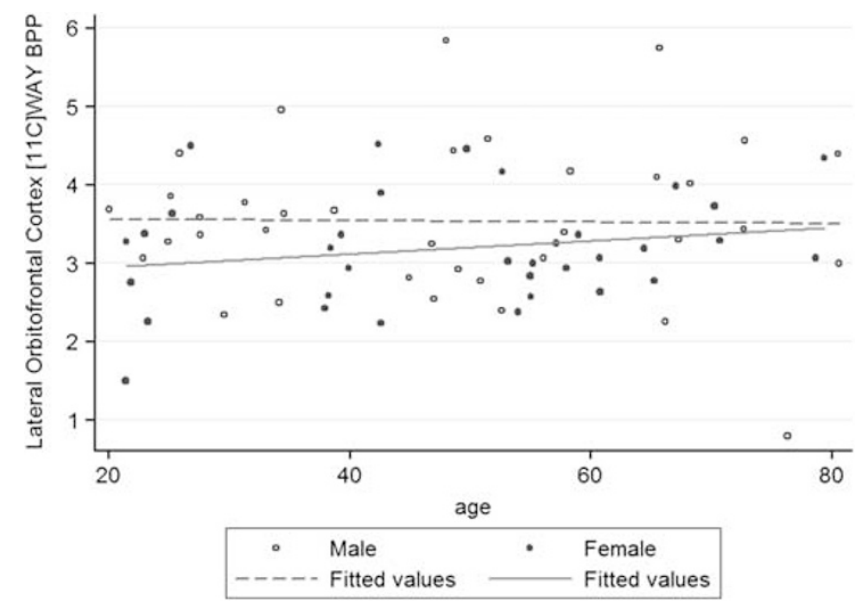

Figure 2 Age- $5 \mathrm{HT}$ IA receptor $\mathrm{BP}_{\mathrm{P}}$ relationships in men and women. There are small differences in sex-age relationships to $5 \mathrm{HTI}$ A receptor $\mathrm{BP}$ in LOF. For women, increased postsynaptic 5HTIA receptor BP was associated with increasing age $(p=0.005)$. In men, there was a tendency for increasing age to be associated with stable or decreasing BP.

For women, increased postsynaptic $5 \mathrm{HT} 1 \mathrm{~A}$ receptor $\mathrm{BP}$ was associated with increasing age $(p=0.005$; Figure 2$)$ and estradiol concentration $(p=0.004$; Supplementary Figure B2; note that slope is small). These associations were small to medium, accounting for $12-21 \%$ of the variance in $\mathrm{BP}$ in these regions. The post hoc regional analyses showed greatest associations in lateral orbitofrontal $(p=0.02)$, occipital $(p=0.02-0.4)$, and pregenual cortices $(0.06-0.08)$. Figure 2 displays how small the sex-related differences are for age-5HT1A receptor associations. The positive relationship between 5HT1A receptor BP and estradiol appeared to be driven by low receptor binding in several premenopausal women with low estradiol values (Supplementary Figure 


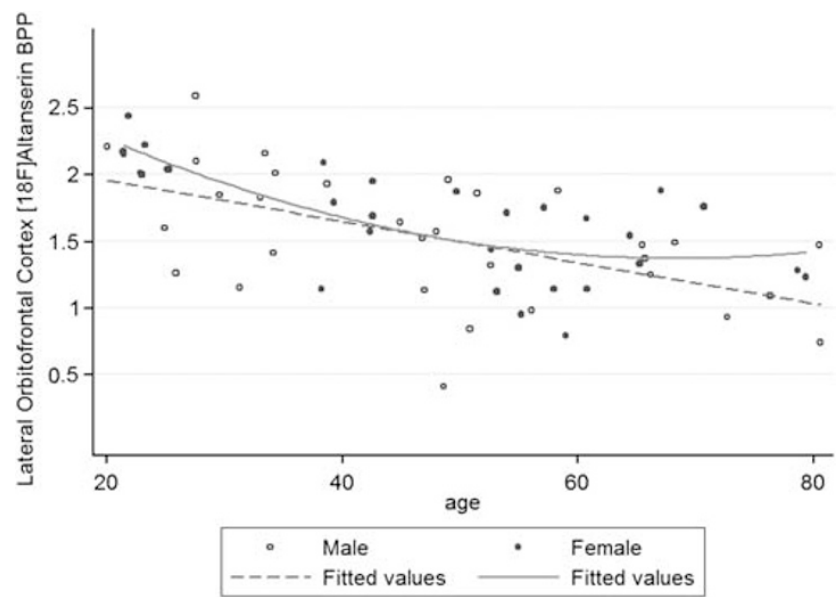

Figure 3 Age-related decreases in cortical $5 \mathrm{HT} 2 \mathrm{~A}$ receptor $\mathrm{BP}_{\mathrm{P}}$ in men and women. The age-related decline ( $\sim 8 \%$ per decade in the full sample) in lateral orbitofrontal cortical 5HT2A receptor $\mathrm{BP}_{\mathrm{p}}$ is representative of all regions of interest. The significance of the distinct model fits for men and women (linear vs curvilinear) is diminished by the lower number of data points at the extremes of age for men (only I man $<23$ years relative to 3 women) and women (only 2 women over age 70 years relative to 4 men) and absence of data for several age categories in the women (27-38 and 70-78 years).

B2). Neither reproductive hormones nor age were significantly related to raphe BP.

\section{HT2A Receptor PET Data}

There was no significant age-by-sex or age ${ }^{2}$-by-sex association with 5HT2A receptor BP (see Table 3). 5HT2A receptor BP decreased significantly with age $(p<0.001)$ as expected, which persisted in the sex-stratified model for men and women. There was a very small, positive, curvilinear relationship of age to 5HT2A BP in the full sample and in women (mean $\beta<0.001$ per decade), but not in men (Figure 3). The significance of the divergence of model fits for men and women is diminished by the lower number of data points at the extremes of age for men (only 1 man $<23$ years relative to 3 women) and women (only 2 women over age 70 years relative to 4 men) and absence of data for several age categories in the women (27-38 and 70-78). There was a trend for women to have higher 5HT2A receptor $\mathrm{BP}_{\mathrm{P}}$ relative to men in amygdala $(p=0.02)$ and pregenual cortex $(p=0.6)$, which was not confirmed in the $\mathrm{BP}_{\mathrm{ND}}$ model (Supplementary Table $\mathrm{C}$ ). Neither estradiol nor FAI was significantly associated with 5HT2A receptor $\mathrm{BP}$.

\section{DISCUSSION}

We found small-to-moderate size associations between 5HT1A/5HT2A receptor $\mathrm{BP}$, sex, age, and reproductive hormones but no age-by-sex interaction relationships. There was a mean $15 \%$ reduction in $5 \mathrm{HT} 1 \mathrm{~A}$ receptor $\mathrm{BP}$ in women relative to men in prefrontal and occipital cortex (post hoc $p=0.03-0.10$ ). Age and reproductive hormones were associated with increases in 5HT1A receptor BP in women $(p=0.004-0.005)$ and borderline significant decreases in 5HT1A receptor BP in men $(p=0.05-0.06)$. Hormone-5HT1A receptor relationships were driven by extreme 5HT1A receptor data in subjects $<50$ years of age with low hormone concentrations. The significant decline in 5HT2A receptor BP relative to age $(8 \%$ per decade) was similar for men and women and was not related to reproductive hormones. Similarity of regression results for $5 \mathrm{HT}$ receptor $\mathrm{BP}_{\mathrm{ND}}$ and $\mathrm{BP}_{\mathrm{P}}$ suggests negligible confounding influences on relationships between age and $V_{\mathrm{ND}}$. These reported findings are discussed below for each receptor system separately.

\section{Serotonin-1A Receptor Binding}

Presynpatic raphe nucleus 5HT1A receptor BP decreased with age ( $4.5 \%$ decrease per decade) in the full sample ( $6 \%$ variance in BP; $p=0.05$ ), which appeared to be driven by trend-level findings in men. The relationship of age with postsynaptic 5HT1A receptor BP tended to be sex dependent, wherein increasing age was associated with increasing BP in women, but stable or decreasing BP in men (Figure 2). These relationships were greatest for women in neocortical regions and for men in hippocampus and raphe. The sex-hormone-5HT1A receptor BP relationships were also sex dependent, wherein increasing FAI was associated with reduced 5HT1A receptor BP in men (most strongly in hippocampus), but increasing estradiol was associated with increased BP in women (primarily neocortex). These hormone-5HT1A receptor relationships were driven by extreme 5HT1A receptor BP values in subjects $<50$ years of age with low hormone concentrations. The combined age and hormone effects were small in men, accounting for $1-9 \%$ of the variance in BP, and small to moderate in women, accounting for $20 \%$ of variance in BP. Our finding of $15 \%$ neocortical $5 \mathrm{HT} 1 \mathrm{~A}$ receptor BP decreases in women relative to men (post hoc $p=0.03-0.10$ ), which exceeds that of test-retest variability in cortical regions (Parsey et al, 2000), but did not reach significance in the overall regression or regional post hoc tests, suggests that this finding warrants additional study. Notably, we observed consistent $5 \mathrm{HT} 1 \mathrm{~A}$ receptor reductions in women relative to men in all brain regions (except in hippocampus where BP was equivalent), although the smaller size of amygdala and raphe regions increased 5HT1A receptor BP measurement variability, thus decreasing the significance of differences.

An incremental decline in presynaptic raphe 5HT1A receptor $\mathrm{BP}$ with aging, particularly for men, and the trend toward an aging-related decline in postsynaptic 5HT1A receptor BP in men, most prominently in hippocampus, could be contributory to neural mechanisms for late-life depression and suicide given strong associations of 5HT1A receptor deficits in these regions with the pathogenesis of MDD and suicide (Arango et al, 1995, 2001; Blier and DeMontigny, 1987; Bowen et al, 1989; Drevets et al, 1999; Mann, 1999; Meltzer et al, 2004; Parsey et al, 2006; Sargent et al, 2000; Stockmeier et al, 1998). Furthermore, a specific age-related decline in hippocampus in men and women could also contribute to aging-related risk for cognitive disturbance (Sarnyai et al, 2000). Androgens were also associated with reductions in 5HT1A receptor BP, similar to preclinical reports (Ricci et al, 2006; Simon et al, 1998; 
Zhang et al, 1999), a relationship most robust in men $<50$ years old. That age and androgen concentration were both associated with 5HT1A receptor reductions, however, argues against a mediating role for male steroid decline in aging-related $5 \mathrm{HT} 1 \mathrm{~A}$ receptor decreases, given that androgen concentrations decrease with aging. Conversely, it is conceivable that the inverse relationship between androgen concentrations and $5 \mathrm{HT} 1 \mathrm{~A}$ receptors might mitigate against larger 5HT1A receptor BP decreases in men in late life. In our previous study where we reported an age-associated decrease in postsynaptic 5HT1A receptor BP in men, there were small age-related increases in $\left[{ }^{11} \mathrm{C}\right] \mathrm{WAY} 100635 V_{\mathrm{ND}}$ (Meltzer et al, 2001). It is notable that in the larger sample in the current study, we observed small age-related decreases in $\left[{ }^{11} \mathrm{C}\right] \mathrm{WAY} 100635 V_{\mathrm{ND}}(p=0.054)$, which may explain why a stronger age-related decline was not detected in this study.

For women, the apparent sex-based decrease in neocortical $5 \mathrm{HT} 1 \mathrm{~A}$ receptor $\mathrm{BP}$, relative to men, appears to be mitigated in later life, as women had age-associated increases in BP. This pattern parallels the epidemiological statistics of greater risk for affective disorders in reproductive-aged women relative to men, which equalizes when women reach menopause (Bebbington et al, 1998; Kessler et al, 1993). A positive relationship between estradiol and 5 HT1A receptor BP was unexpected based on animal literature data of $5 \mathrm{HT} 1 \mathrm{~A}$ receptor density and expression reductions after estradiol administration (Osterlund et al, 2000; Osterlund and Hurd, 1998). Premenopausal women with both low estradiol concentrations and low 5HT1A receptor $\mathrm{BP}$ appeared to be driving this association. As with men, in women, age and sex steroids appeared to have opposite effects on 5HT1A receptor $\mathrm{BP}$, which may mitigate against larger age-related changes.

Whether the sex, age, and hormone effects accounting for $9-20 \%$ of the variance in 5HT1A receptor BP exert behavioral effects is not known from this study design. Certainly, the complete absence of 5HT1A receptors was associated with high levels of behavioral inhibition and depressive behavior (5HT1A knockout model; Ramboz et al, 1998) and reductions were associated with MDD (Drevets et al, 2000) and anxiety disorders (Lanzenberger et al, 2007). As postsynaptic 5HT1A receptors also serve functions such as gating action potentials of hippocampal CA1 pyramidal cells and stimulating glial release of trophic factors that promote 5HT neuronal outgrowth (Azmitia, 1999), it is conceivable that small age-sex-hormone associations with $5 \mathrm{HT} 1 \mathrm{~A}$ receptor binding could increase affective disorder risk in vulnerable individuals. Furthermore, extremely high androgen or low estradiol concentrations in young men and women, respectively, appear to have important effects on $5 \mathrm{HT} 1 \mathrm{~A}$ receptor $\mathrm{BP}$.

The validity of the 5HT1A receptor $\mathrm{BP}$ findings is strengthened by our control for potential age-sex effects on plasma $f_{\mathrm{p}}$ and nonspecific binding $\left(V_{\mathrm{ND}}\right)$. Although the age-by-sex interaction effect on WAY100635 $f_{\mathrm{p}}$ is noteworthy (age-associated increase in men and decrease in women), and replicates a previous trend (Parsey et al, 2002), we confirmed that this did not impact $\mathrm{BP}_{\mathrm{P}}$ model results when $f_{\mathrm{p}}$ was added as a covariate (Supplementary Table B). Furthermore, we confirmed that $\mathrm{BP}_{\mathrm{ND}}$ model results (Supplementary Tables A and C), which do not rely upon $f_{\mathrm{p}}$, were consistent with $\mathrm{BP}_{\mathrm{P}}$ model results. Similarly, the trend finding of age-associated decreases in $\left.{ }^{11} \mathrm{C}\right]$ WAY 100635 cerebellar $V_{\mathrm{T}}$ in the full sample did not influence the model results because of close consistency between $\mathrm{BP}_{\mathrm{ND}}$ and the $\mathrm{BP}_{\mathrm{P}}$ model results, the latter of which does not rely on free and nonspecific radiotracer binding in brain. We found no sex differences in $\left[{ }^{11} \mathrm{C}\right]$ WAY100635 $V_{\mathrm{ND}}$.

\section{Serotonin-2A Receptor Binding}

We found $\sim 8 \%$ decreases in 5HT2A receptor BP per decade of age across the full sample of men and women, similar to that reported previously (Adams et al, 2004). Although we were able to replicate the finding of Sheline et al (2002) of a nonlinear inverse relationship between $\mathrm{BP}$ and age in women, lack of data for age extremes (particularly for younger men and older women) limits the ability of these data to support differential age-related patterns of 5HT2A receptor decreases in women $v s$ men (Figure 3).

Endogenous estradiol was not associated with 5HT2A receptor $\mathrm{BP}$ in women, which replicates one study in women (Frokjaer et al, 2008), but contrasts with a study in healthy men that described a positive association between estradiol and neocortical 5HT2A receptor BP (Frokjaer et al, 2010). It is noteworthy that the regression coefficient $(0.06-0.17)$ for estradiol in our models of neocortical 5HT2A approximates that found in men (Frokjaer et al, 2010), suggesting we may have been underpowered to detect the significance of an estradiol-5HT2A relationship in our female subgroup. FAI was not associated with 5HT2A receptor BP; however, we did not measure estradiol in men and therefore cannot assess whether aromatization of testosterone to estradiol was related to receptor BP. The trend finding of increased $5 \mathrm{HT} 2 \mathrm{~A}$ receptor $\mathrm{BP}_{\mathrm{P}}$ in women is negated by the finding of no sex difference for $5 \mathrm{HT} 2 \mathrm{~A}$ receptor $\mathrm{BP}_{\mathrm{ND}}$ in this sample and the absence of sex differences in a larger cohort $(n=136)$ (Erritzoe et al, 2009), and other studies (Biver et al, 1996; Frokjaer et al, 2009; Meyer et al, 1999; Rosier et al, 1996).

Increased 5HT2A receptor binding is associated with neuroticism, depression, suicide, and eating disorders. Hypotheses abound regarding whether these findings relate to genetic expression of the receptor or regulation relative to central 5HT tone. In the case of aging, the loss of 5HT2A receptors is expected to be a result of aging-related loss of neuropil, as these receptors predominantly are on pyramidal cells. Because of the role of 5-HT2A receptors in stimulating downstream neurons (Barnes and Sharp, 1999; Sharp et al, 2007), their diminution over aging are hypothesized to contribute to aging-related deficits in cognition, sleep, and mood (Meltzer et al, 1998).

Similar to what we noted for $\left[{ }^{11} \mathrm{C}\right] \mathrm{WAY} 100635$, the validity of $\left[{ }^{18} \mathrm{~F}\right]$ altanserin findings is strengthened by our control for potential age-sex effects on plasma free radiotracer fraction $\left(f_{\mathrm{p}}\right)$ and nonspecific binding $\left(V_{\mathrm{ND}}\right)$. For $\left[{ }^{18} \mathrm{~F}\right]$ altanserin, increasing age was associated with increasing cerebellar $V_{\mathrm{T}}$ in the full sample as previously reported (Adams et al, 2004; Eastwood et al, 2001; Meltzer et al, 1998) and in women alone. In women, estradiol concentrations were also associated with increasing cerebellar $V_{\mathrm{T}}$ as 
previously described in men (Frokjaer et al, 2010). Age and estradiol relationships with $V_{\mathrm{ND}}$ may be contributory, but are not thought to influence the BP outcomes, as the same age and estradiol-associated decreases observed for altanserin $\mathrm{BP}_{\mathrm{ND}}$ were also present for altanserin $\mathrm{BP}_{\mathrm{P}}$. The tendency for increased cerebellar $V_{\mathrm{T}}$ in women relative to men concurs with one (Adams et al, 2004) but not another study (Erritzoe et al, 2009), and does not appear to impact BP in our study. Some have considered using an alternative reference region, although the pons is fraught with its own problems (see Adams et al, 2004).

In contrast to a prior study (Adams et al, 2004), we found no age-sex relationships to metabolism of $\left[{ }^{18} \mathrm{~F}\right]$ altanserin over the scan duration, which suggests that there were no age-sex discrepancies in blood-brain barrier-permeable radiolabeled metabolites (Smith et al, 1998). Additionally, there were no sex or age effects on altanserin $f_{\mathrm{p}}$, which concurs with absence of sex differences in $f_{\mathrm{p}}$ reported previously (Adams et al, 2004). Nonetheless, it is important to note that the plasma-derived Logan BP is expected to underestimate the dual-input compartmental modeling BP value (this model accounts for blood-brain barrier passage of radiometabolites) by about $30 \%$, whereas correlation between the BP values is very high $(r \sim 1.0)$ (Price et al, $2002 a, b)$. This underestimation reflects overestimation of nonspecific binding in the cerebellar reference region.

Although BMI has been related to $5 \mathrm{HT} 2 \mathrm{~A}$ receptor $\mathrm{BP}$ in other studies (Erritzoe et al, 2009), the effect size in this data set was too small $\left(\beta=1 \times 10^{-5}\right)$ to be considered clinically meaningful and therefore was excluded from the model.

\section{CONCLUSIONS}

The strengths of this study included: (1) robust and wellvalidated methods for quantification of atrophy-corrected 5HT1A and 5HT2A receptor BP with careful control for nonspecific effects of age and sex on radioligand free fraction and cerebellar $V_{\mathrm{T}}$, (2) characterization and standardization of reproductive status and associated endogenous hormonal exposures, (3) thorough screening for and exclusion of individuals with personal psychiatric history, and (4) relatively large subject sample by PET standards with a wide age span of men and women, although a higher number of altanserin scans in subjects over age 70 years would have been desirable.

In conclusion, aside from the well-known age effects to decrease $5 \mathrm{HT} 2 \mathrm{~A}$ receptor $\mathrm{BP}$, at most $9-20 \%$ of $5 \mathrm{HT} 1 \mathrm{~A}$ and $2 \mathrm{~A}$ receptor $\mathrm{BP}$ variance was explained by sex, age, and reproductive hormone effects and there were no age-by-sex interactions with receptor binding. Endocrine standardization minimized confounding introduced by endogenous hormonal fluctuations and reproductive stage and permitted us to detect small effects of sex, age, and endogenous sex steroid exposures upon 5HT1A binding. Although these effect sizes are small, they could potentially lower the threshold for illness in individuals with genetic and/or environmental vulnerabilities for affective disorders. In addition, low hormone concentrations in adults $<50$ years of age may be associated with more extreme 5HT1A receptor $\mathrm{BP}$ values, but remains to be studied further.

\section{ACKNOWLEDGEMENTS}

This research study was supported by R01s MH67602 and MH71944. Support to CC Meltzer, EL Moses-Kolko, S Berga, SM Sereika, JC Price, R Coleman, and C Becker was provided by R01 MH067602. Dr Price received additional support through K02 AG027998, and EL Moses-Kolko received additional support through RO1 MH079164. Support for Nilesh Shah was through 5T32 GM074927. Support for Patrick M Fisher was through the Multi-modal Neuroimaging Training Program at the University of Pittsburgh (DA023420).

\section{DISCLOSURE}

Dr Moses-Kolko received a small honorarium as a guest speaker for La Leche League regional conference, Summer 2009. Over the past 3 years, N Scott Mason has received compensation from Janssen Pharmaceuticals, Elan Pharmaceuticals, Banner Alzheimer's Institute, and the Gollman Group (Dallas, TX). Dr Sarah Berga has served on the Board of Directors and as a consultant for numerous organizations (itemized below). Member of University of Virginia Medical Alumni Association Board of Directors, 2007 to present (Gratis); consultant for Agile Therapeutics Medical Advisory Board-March 2011; AHC Media, LLC-consultant, Annual business meeting-April 2008, April 2009, June 2010, Noven Pharmaceutical Medical Advisory Board-Feb 2010, Promedica Communications - Bayer Pharmaceutical Medical Advisory Board, Meeting - June 2009, August 2009, Watson Pharmaceutical Women's Health Strategic Advisory Board-April 2010; Legal consulting for Kirkland and Ellis, LLCLeydig, Voit \& Mayer, LLC, and Reed Smith, LLC; Editorial board for ACOG, Editorial Committee, Guidelines for Women's Health Care, 2009-2011 (Gratis), American Journal of Obstetrics and Gynecology, 2003 to present (Gratis), Advisory Board for Subspecialty Neuroendocrinology and Reproductive Neurobiology, The Endocrine Society Member, Endocrine Self-Assessment Program Committee (June 2007-June 2011), Clinical Practice Guideline Task Force on Hypothalamic Amenorrhea, January 2011 to present (Gratis), Editorial Board for Endocrinology, January 2010 to present (Gratis), Menopause, Editorial Board, 1999 to present (Gratis). NIH Study Section reviewer; Society for Women's Health Research, ISIS CVD Network Member, 2009 to present; UpToDate Peer Review Board, 2005 to present. Julie C Price, Susan M Sereika, Patrick M Fisher, Rhaven Coleman, Carl Becker, Tammy Loucks, Carolyn C Meltzer, and Nilesh Shah declare no conflict of interest.

\section{REFERENCES}

Adams KH, Pinborg LH, Svarer C, Hasselbalch SG, Holm S, Haugbol S et al (2004). A database of [(18)F]-altanserin binding to $5-\mathrm{HT}(2 \mathrm{~A})$ receptors in normal volunteers: normative data and relationship to physiological and demographic variables. Neuroimage 21: 1105-1113.

Arango V, Underwood MD, Boldrini M, Tamir H, Kassir SA, Hsiung $S$ et al (2001). Serotonin 1A receptors, serotonin transporter binding and serotonin transporter mRNA expression 
in the brainstem of depressed suicide victims. Neuropsychopharmacology 25: 892-903.

Arango V, Underwood MD, Gubbi AV, Mann JJ (1995). Localized alterations in pre- and postsynaptic serotonin binding sites in the ventrolateral prefrontial cortex of suicide victims. Brain Res 688: $121-133$.

Azmitia EC (1999). Serotonin neurons, neuroplasticity, and homeostasis of neural tissue. Neuropsychopharmacology 21: 2S.

Bailer UF, Frank GK, Henry SE, Price JC, Meltzer CC, Weissfeld L et al (2005). Altered brain serotonin 5-HT1A receptor binding after recovery from anorexia nervosa measures by positron emission tomography and [11C]WAY 100635. Arch Gen Psychiatry 62: 1032-1041.

Barnes NM, Sharp T (1999). A review of central 5-HT receptors and their function. Neuropharmacology 38: 1083-1152.

Bebbington P, Dunn G, Jenkins R, Lewis G, Brugha T, Farrell M et al (1998). The influence of age and sex on the prevalence of depressive conditions: report from the National Survey of Psychiatric Morbidity. Psychol Med 28: 9-19.

Biver F, Lotstra F, Monclus M, Wikler D, Damhaut P, Mendlewicz J et al (1996). Sex difference in 5HT2 receptor in the living human brain. Neurosci Lett 204: 25-28.

Blier P, DeMontigny C (1987). Modification of 5-HT neuron properties by sustained administration of the 5HT1A agonist gepirone: electrophysiological studies in the rat brain. Synapse 1: $470-480$.

Bowen DM, Najlerahim A, Procter AW, Francis PT, Murphy E (1989). Circumscribed changes of the cerebral cortex in neuropsychiatric disorders of late life. Proc Natl Acad Sci USA 86: 9504-9508.

Cheetham SC, Crompton MR, Katona CL, Horton RW (1990). Brain 5-HT1 binding sites in depressed suicides. Psychopharmacology (Berl) 102: 544-548.

Costes N, Merlet I, Ostrowsky K, Faillenot I, Lavenne F, Zimmer L et al (2005). A 18F-MPPF PET normative database of 5-HT1A receptor binding in men and women over aging. J Nucl Med 46: 1980-1989.

Cyr M, Bosse R, Di Paolo T (1998). Gonadal hormones modulate 5hydroxytryptamine2A receptors: emphasis on the rat frontal cortex. Neuroscience 83: 829-836.

David SP, Murthy NV, Rabiner EA, Munafo MR, Johnstone EC, Jacob $\mathrm{R}$ et al (2005). A functional genetic variation of the serotonin $(5-\mathrm{HT})$ transporter affects 5 -HT1A receptor binding in humans. J Neurosci 25: 2586-2590.

Drevets WC, Frank E, Price JC, Kupfer DJ, Greer PJ, Mathis C (2000). Serotonin type-1A receptor imaging in depression. $\mathrm{Nucl}$ Med Biol 27: 499-507.

Drevets WC, Frank E, Price JC, Kupfer DJ, Holt D, Greer PJ et al (1999). PET imaging of serotonin 1A receptor binding in depression. Biol Psychiatry 46: 1375-1387.

Drevets WC, Thase ME, Moses-Kolko EL, Price J, Frank E, Kupfer DJ et al (2007). Serotonin-1A receptor imaging in recurrent depression: replication and literature review. Nucl Med Biol 34: 865-877.

Eastwood SL, Burnet PW, Gittins R, Baker K, Harrison PJ (2001). Expression of serotonin 5-HT(2A) receptors in the human cerebellum and alterations in schizophrenia. Synapse 42: 104-114.

Erritzoe D, Frokjaer VG, Haugbol S, Marner L, Svarer C, Holst K et al (2009). Brain serotonin 2A receptor binding: relations to body mass index, tobacco and alcohol use. Neuroimage 46: 23-30.

Feldman HA, Longcope C, Derby CA, Johannes CB, Araujo AB, Coviello AD et al (2002). Age trends in the level of serum testosterone and other hormones in middle-aged men: longitudinal results from the Massachusetts male aging study. J Clin Endocrinol Metab 87: 589-598.

First MB, Spitzer RL, Gibbon M, Williams JBW (1998). Structured Clinical Interview for DSM-IV Axis I Disorders - Patient Edition.
New York State Psychiatric Institute, Biometrics Research Department: New York.

Fisher P, Meltzer C, Ziolko S, Price J, Moses-Kolko E, Serga S et al (2006). Capacity for 5-HT1A-mediated autoregulation predicts amygdala reactivity. Nat Neurosci 9: 1362-1363.

Fisher PM, Meltzer CC, Price JC, Coleman RL, Ziolko SK, Becker C et al (2009). Medial prefrontal cortex 5-HT2A density is correlated with amygdala reactivity, response habituation, and functional coupling. Cereb Cortex 19: 2499-2507.

Frokjaer VG, Erritzoe D, Juul A, Nielsen FA, Holst K, Svarer C et al (2010). Endogenous plasma estradiol in healthy men is positively correlated with cerebral cortical serotonin $2 \mathrm{~A}$ receptor binding. Psychoneuroendocrinology 35: 1311-1320.

Frokjaer VG, Erritzoe D, Madsen J, Paulson OB, Knudsen GM (2009). Gender and the use of hormonal contraception in women are not associated with cerebral cortical 5-HT $2 \mathrm{~A}$ receptor binding. Neuroscience 163: 640-645.

Frokjaer VG, Mortensen EL, Nielsen FÅ, Haugbol S, Pinborg LH, Adams KH et al (2008). Frontolimbic serotonin 2A receptor binding in healthy subjects is associated with personality risk factors for affective disorder. Biol Psychiatry 63: 569-576.

Hamilton M (1960). A rating scale for depression. J Neurol Neurosurg Psychiatry 23: 56-62.

Haugbol S, Pinborg LH, Arfan HM, Frokjaer VM, Madsen J, Dyrby TB et al (2007). Reproducibility of 5-HT2A receptor measurements and sample size estimations with [18F]altanserin PET using a bolus/infusion approach. Eur J Nucl Med Mol Imaging 34: 910-915.

Henry SE, Bailer UF, Frank GK, Meltzer CC, Price JC, Mathis CA et al (2004). Positive relationships between 5HT2A receptor activity in frontal cortical regions after recovery from bulimia nervosa. Biol Psychiatry 55: 105S.

Innis RB, Cunningham VJ, Delforge J, Fujita M, Gjedde A, Gunn $\mathrm{RN}$ et al (2007). Consensus nomenclature for in vivo imaging of reversibly binding radioligands. J Cereb Blood Flow Metab 27: 1533-1539.

Jovanovic H, Cerin A, Karlsson P, Lundberg J, Halldin C, Nordström AL (2006). A PET study of 5-HT1A receptors at different phases of the menstrual cycle in women with premenstrual dysphoria. Psychiatry Res Neuro 148: 185-193.

Jovanovic H, Lundberg J, Karlsson P, Cerin A, Saijo T, Varrone A et al (2008). Sex differences in the serotonin 1A receptor and serotonin transporter binding in the human brain measured by PET. Neuroimage 39: 1408-1419.

Kessler RC, McGonagle KA, Swartz M, Blazer DG, Nelson CB (1993). Sex and depression in the National Comorbidity Survey I: lifetime prevalence, chronicity and recurrence. J Affect Disord 29: 85-96.

Kugaya A, Epperson CN, Zoghbi S, van Dyck CH, Hou Y, Fujita M et al (2003). Increase in prefrontal cortex serotonin 2A receptors following estrogen treatment in postmenopausal women. Am J Psychiatry 160: 1522-1524.

Lammertsma AA, Hume SP (1996). Simplified reference tissue model for PET receptor studies. Neuroimage 4(3 Part 1): 153-158.

Lanzenberger RR, Mitterhauser M, Spindelegger C, Wadsak W, Klein N, Mien L-K et al (2007). Reduced serotonin-1A receptor binding in social anxiety disorder. Biol Psychiatry 61: 1081-1089.

Lemaire C, Cantineau R, Guillaume M, Plenevaux A, Christiaens L (1991). Fluorine-18-altanserin: a radioligand for the study of serotonin receptors with PET: radiolabeling and in vivo biologic behavior in rats. J Nucl Med 32: 2266-2272.

Logan J, Fowler JS, Volkow ND, Ding YS, Wang G-J, Alexoff DL (2001). A strategy for removing the bias in the graphical analysis method. J Cereb Blood Flow Metab 21: 307-320.

Mann JJ (1999). Role of the serotonergic system in the pathogenesis of major depression and suicidal behavior. Neuropsychopharmacology 21(2 Suppl): 99S-105S. 
Matsubara S, Arora RC, Meltzer HY (1991). Serotonergic measures in suicide brain: 5-HT1A binding sites in frontal cortex of suicide victims. J Neural Transm Gen Sect 85: 181-194.

McCarron JA, Turton D, Pike VW, Poole K (1996). Remotely controlled production of the 5HT1A receptor radioligand, [carbonyl-11C]WAY-100635, via 11C-carboxylation of an immobilized Grignard reagent. J Labelled Comp Radiopharm 38: 941-953.

Meltzer C, Kinahan P, Nichols T, Greer P, Comtat C, Cantwell M et al (1999). Comparative evaluation of MR-based partial volume correction schemes for PET. J Nucl Med 40: 2053-2065.

Meltzer CC, Drevets WC, Price JC, Mathis CA, Lopresti B, Greer PJ et al (2001). Gender-specific aging effects on the serotonin 1A receptor. Brain Res 895: 9-17.

Meltzer CC, Leal JP, Mayberg HS, Wagner HJ, Frost JJ (1990). Correction of PET data for partial volume effects in human cerebral cortex by MR imaging. J Comput Assist Tomogr 14: $561-570$.

Meltzer CC, Price JC, Mathis CA, Butters MA, Ziolko SK, MosesKolko E et al (2004). Serotonin $1 \mathrm{~A}$ receptor binding and treatment response in late-life depression. Neuropsychopharmacology 29: 2258-2265.

Meltzer CC, Smith G, DeKosky ST, Pollock BG, Mathis CA, Moore RY et al (1998). Serotonin in aging, late-life depression, and Alzheimer's disease: the emerging role of functional imaging (see comment). Neuropsychopharmacology 18: 407-430.

Meyer JH (2008). Applying neuroimaging ligands to study major depressive disorder. Semin Nucl Med 38: 287-304.

Meyer JH, Kapur S, Houle S, DaSilva J, Owczarek B, Brown GM et al (1999). Prefrontal cortex 5-HT2 receptors in depression: an $[18 \mathrm{~F}]$ setoperone PET imaging study. Am J Psychiatry 156: 1029-1034.

Moses EL, Drevets WC, Smith G, Mathis CA, Kalro BN, Butters MA et al (2000). Effects of estradiol and progesterone administration on human serotonin $2 \mathrm{~A}$ receptor binding: a PET study. Biol Psychiatry 48: 854-860.

Osterlund MK, Halldin C, Hurd YL (2000). Effects of chronic 17beta-estradiol treatment on the serotonin 5-HT(1A) receptor mRNA and binding levels in the rat brain. Synapse 35: $39-44$.

Osterlund MK, Hurd YL (1998). Acute 17 beta-estradiol treatment down-regulates serotonin 5HT1A receptor mRNA expression in the limbic system of female rats. Brain Res Mol Brain Res 55: 169-172.

Palego L, Marazziti D, Rossi A, Giannaccini G, Naccarato AG, Lucacchini A et al (1997). Apparent absence of aging and gender effects on serotonin 1A receptors in human neocortex and hippocampus. Brain Res 758: 26-32.

Parsey RV, Arango V, Olvet DM, Oquendo MA, Van Heertum RL, Mann JJ (2005). Regional heterogeneity of 5-HT1A receptors in human cerebellum as assessed by positron emission tomography. J Cereb Blood Flow Metab 25: 785-793.

Parsey RV, Oquendo MA, Ogden RT, Olvet DM, Simpson N, Huang $\mathrm{Y}$ et al (2006). Altered serotonin 1A binding in major depression: a [carbonyl-C-11]WAY 100635 positron emission tomography study. Biol Psychiatry 59: 106-113.

Parsey RV, Oquendo MA, Simpson NR, Ogden RT, Van Heertum $\mathrm{R}$, Arango $\mathrm{V}$ et al (2002). Effects of sex, age, and aggressive traits in man on brain serotonin 5-HT1A receptor binding potential measured by PET using [C-11]WAY-100635. Brain Res 954: $173-182$.

Parsey RV, Slifstein M, Hwang DR, Abi-Dargham A, Simpson N, Mawlawi $\mathrm{O}$ et al (2000). Validation and reproducibility of measurement of $5 \mathrm{HT} 1 \mathrm{~A}$ receptor parameters with [carbonyl11C]WAY-100635 in human: comparison of arterial and reference tissue input functions. J Cereb Blood Flow Metab 20: 1111-1133.
Pecins-Thompson M, Bethea CL (1999). Ovarian steroid regulation of serotonin-1A autoreceptor messenger RNA expression in the dorsal raphe of rhesus macaques. Neuroscience 89: 267-277.

Price JC, Kelley DE, Ryan CM, Meltzer CC, Drevets WC, Mathis CA et al (2002b). Evidence of increased serotonin-1A receptor binding in type 2 diabetes: a positron emission tomography study. Brain Res 927: 97-103.

Price JC, Xu L, Mazumdar S, Meltzer CC, Drevets WC, Mathis CA et al (2002a). Impact of graphical analysis bias on group comparisons of regional [carbonyl-11C]WAY binding potential measures. Neuroimage 16: S72.

Rabiner EA, Messa C, Sargent PA, Husted-Kjaer K, Montgomery A, Lawrence $\mathrm{AD}$ et al (2002). A database of [(11)C]WAY-100635 binding to 5-HT(1A) receptors in normal male volunteers: normative data and relationship to methodological, demographic, physiological, and behavioral variables. Neuroimage 15: $620-632$.

Ramboz S, Oosting R, Amara DA, Kung HF, Blier P, Mendelsohn M et al (1998). Serotonin receptor 1A knockout: an animal model of anxiety-related disorder. Neurobiology 95: 14476-14481.

Ricci LA, Rasakham K, Grimes JM, Melloni JRH (2006). Serotonin$1 \mathrm{~A}$ receptor activity and expression modulate adolescent anabolic/androgenic steroid-induced aggression in hamsters. Pharmacol Biochem Behav 85: 1-11.

Rosier A, Dupont P, Peuskens J, Bormans G, Vandenberghe R, Maes $M$ et al (1996). Visualisation of loss of 5-HT2A receptors with age in healthy volunteers using [18F]altanserin and positron emission tomographic imaging. Psychiatry Res 68: $11-22$.

Sargent PA, Kjaer KH, Bench CJ, Rabiner EA, Messa C, Meyer J et al (2000). Brain serotonin 1A receptor binding measured by positron emission tomography with [11C]WAY-100635: effects of depression and antidepressant treatment. Arch Gen Psychiatry 57: $174-180$.

Sarnyai Z, Sibille EL, Pavlides C, Fenster RJ, McEwen BS, Toth M (2000). Impaired hippocampal-dependent learning and functional abnormalities in the hippocampus in mice lacking serotonin(1A) receptors. Proc Natl Acad Sci USA 97: 14731-14736.

Sharp T, Boothman L, Raley J, Queree P (2007). Important messages in the 'post': recent discoveries in 5-HT neurone feedback control. Trends Pharmacol Sci 28: 629-636.

Sheline YI, Mintun MA, Moerlein SM, Snyder AZ (2002). Greater loss of $5-\mathrm{HT}(2 \mathrm{~A})$ receptors in midlife than in late life. Am J Psychiatry 159: 430-435.

Simon NG, Cologer-Clifford A, Lu S-f, McKenna SE, Hu S (1998). Testosterone and its metabolites modulate 5HT1A and 5HT1B agonist effects on intermale aggression. Neurosci Biobehav Rev 23: $325-336$

Smith GS, Price JC, Lopresti BJ, Huang Y, Simpson N, Holt D et al (1998). Test-retest variability of serotonin 5-HT2A receptor binding measured with positron emission tomography and [18F]altanserin in the human brain. Synapse 30: 380-392.

Soloff PH, Price JC, Mason NS, Becker C, Meltzer CC (2010). Gender, personality, and serotonin-2A receptor binding in healthy subjects. Psychiatry Res 181: 77-84.

Soules MR, Sherman S, Parrott E, Rebar R, Santoro N, Utian W et al (2001). Executive summary: Stages of Reproductive Aging Workshop (STRAW). Fertil Steril 76: 874-878.

Stein P, Savli M, Wadsak W, Mitterhauser M, Fink M, Spindelegger $\mathrm{C}$ et al (2008). The serotonin-1A receptor distribution in healthy men and women measured by PET and [carbonyl-11C]WAY100635 (see comment). Eur J Nucl Med Mol Imaging 35: 2159-2168.

Stockmeier CA, Shapiro LA, Dilley GE, Kolli TN, Friedman L, Rajkowska G (1998). Increase in serotonin-1A autoreceptors in 
the midbrain of suicide victims with major depressionpostmortem evidence for decreased serotonin activity. J Neurosci 18: 7394-7401.

Sumner BE, Fink G (1995). Estrogen increases the density of 5HT2A receptors in cerebral cortex and nucleus accumbens in the female rat. J Steroid Biochem Mol Biol 54(1/2): 15-20.

Sumner BE, Fink G (1998). Testosterone as well as estrogen increases serotonin2A receptor mRNA and binding site densities in the male rat brain. Brain Res Mol Brain Res 59: 205-214.

Szanto K, Gildengers A, Mulsant BH, Brown G, Alexopoulos GS, Reynolds III CF (2002). Identification of suicidal ideation and prevention of suicidal behaviour in the elderly. Drugs Aging 19: $11-24$.

Tauscher J, Verhoeff NP, Christensen BK, Hussey D, Meyer JH, Kecojevic A et al (2001). Serotonin 5-HT1A receptor binding potential declines with age as measured by [11C]WAY-100635 and PET. Neuropsychopharmacology 24: 522-530.

Woods RP, Mazziotta JC, Cherry SR (1993). MRI-PET registration with automated algorithm. J Comput Assist Tomogr 17: 536-546.

Zhang L, Ma W, Barker JL, Rubinow DR (1999). Sex differences in expression of serotonin receptors (subtypes $1 \mathrm{~A}$ and $2 \mathrm{~A}$ ) in rat brain: a possible role of testosterone. Neuroscience 94: 251-259.

Supplementary Information accompanies the paper on the Neuropsychopharmacology website (http://www.nature.com/npp) 